\title{
Combined ostracod and planktonic foraminiferal biozonation of the Late Coniacian - Early Maastrichtian in Israel
}

\author{
Avraham HONIGSTEIN, Ahuva ALMOGI-LABIN \& Amnon ROSENFELD \\ Tel-Aviv University, Department of Geophysics \& Planetary Science, Tel Aviv 69978 \\ Department of Geology, Institute of Earth Sciences, The Hebrew University of Jerusalem, Jerusalem 91904 \& \\ Geological Survey of Israel, 30 Malkhe Israel St., Jerusalem 95501, Israel
}

\begin{abstract}
The distribution and zonation of planktonic foraminifera and ostracods during the Late Coniacian - Early Maastrichtian succession in Israel was studied in detail from six surface sections. The combination of contemporaneous biozones led to a more accurate age determination of the local ostracod zones, according to the Tethyan planktonic foraminiferal zonation. The configuration of the biozones of both taxa presents more datum lines for stratigraphic correlation of the Senonian strata of Israel. Three new ostracod species were described from Campanian sediments: Cytherelloidea zinensis, Loxoconcha hebraica and Cristaeleberis ordinata.
\end{abstract}

\section{INTRODUCTION}

Late Coniacian - Maastrichtian marine formations of the Mount Scopus Group (Flexer, 1968) are widely distributed in Israel. They are mostly composed of chalks, marls, cherts and phosphorites. A renewed interest in Senonian rocks of Israel was evoked after the micropaleontological studies of Moshkovitz (1984; calcareous nannofossils) and Honigstein (1983, 1984; ostracods). Additional biostratigraphic data on ostracods are recorded in Lipson-Benitah et al. (1985; combined with foraminifera) and in Lifshitz et al. (1985). Reiss et al. (1985) summarised multiple bio- and chronostratigraphic data from the Senonian of Israel, based on ranges of indicative species of megafossils (mainly ammonites), planktonic and benthic foraminifera, calcareous nannoplankton, and ostracods. A modified biostratigraphic chart, on the base of ranges of 54 Globotruncanidae species, was presented in Almogi-Labin et al. (1986) and the results were compared with the general European zonation of Robaszynski et al. (1984). In this study, the local ostracod zones are correlated with the more general planktonic foraminiferal zonation.

The combined biozonation is based on former results (Honigstein, 1983, Reiss et al., 1985) and on six additional surface sections (Table 1, coordinates in Israel grid; Fig. 1). These profiles were chosen to be representative for a detailed bio-, litho- and chronostratigraphic study. Studies on other microfossil groups (from the same "type-" sections) are in preparation. Both planktonic foraminifera and ostracods were studied from the same samples, except those of the Ein Fawwar section (see Fig. 1). The distribution of the planktonic foraminifera and their ranges were determined here by Almogi-Labin and the ostracods by
Honigstein and Rosenfeld. The results are depicted in Figs. 3-12. Species with limited taxonomic and stratigraphic importance are omitted, such as Arcaeoglobigerina cretacea and $A$. blowi (foraminifera), and Bythocrypris windhami, Cytherella cf. C. austinensis, Buntonia? aff. B. cretacea, Bairdoppilata pondera and Spinoleberis megiddoensis (ostracods). The investigation of more than 400 samples led also to a modification of the general distribution chart of Senonian ostracods from Israel (Fig. 2). A calibrated scheme of ostracod versus planktonic foraminiferal zones is given in Fig. 13.

The samples from the studied sections, their washed residues, as well as the picked foraminifera, are deposited in the Micropaleontological Collection of the Geological Department of the Hebrew University, Jerusalem, catalogued with the Laboratory prefix HU-. The ostracod material is stored at the Micropaleontological Laboratory of the Geological Survey of Israel. Jerusalem.

\section{TAXONOMIC NOTES Ostracoda}

Most of the ostracod species and their ranges were described in Honigstein (1984). There, six ostracod assemblage zones were established within the Late Coniacian - Maastrichtian sequence in all parts of Israel. Each zone begins with the first appearance of diagnostic species (and assemblages) and is named after one of these indicative species. Five species were hitherto not recorded from the Senonian of Israel and are described in the present study, three of which are new species. The modified general distribution of the ostracod species during the Senonian is shown in Fig. 2. 
Genus Cytherelloidea Alexander, 1929

Cytherelloidea zinensis Honigstein \& Rosenfeld sp. nov.

(PI. 1, figs. 1-4)

(Type No. 315)

Derivation of name. From the type location, the Nahal Zin in southern Israel.

Holotype. Male carapace, HU-6837 (Pl. 1, fig. 3).

Paratypes. Two male and one female carapaces (PI. 1, figs. 1, 2, 4).

Type locality and horizon. Nahal Zin, SMA 34, coord. 1538/0303. Mishash Formation.

Diagnosis. Cytherelloidea with entirely pitted surface.

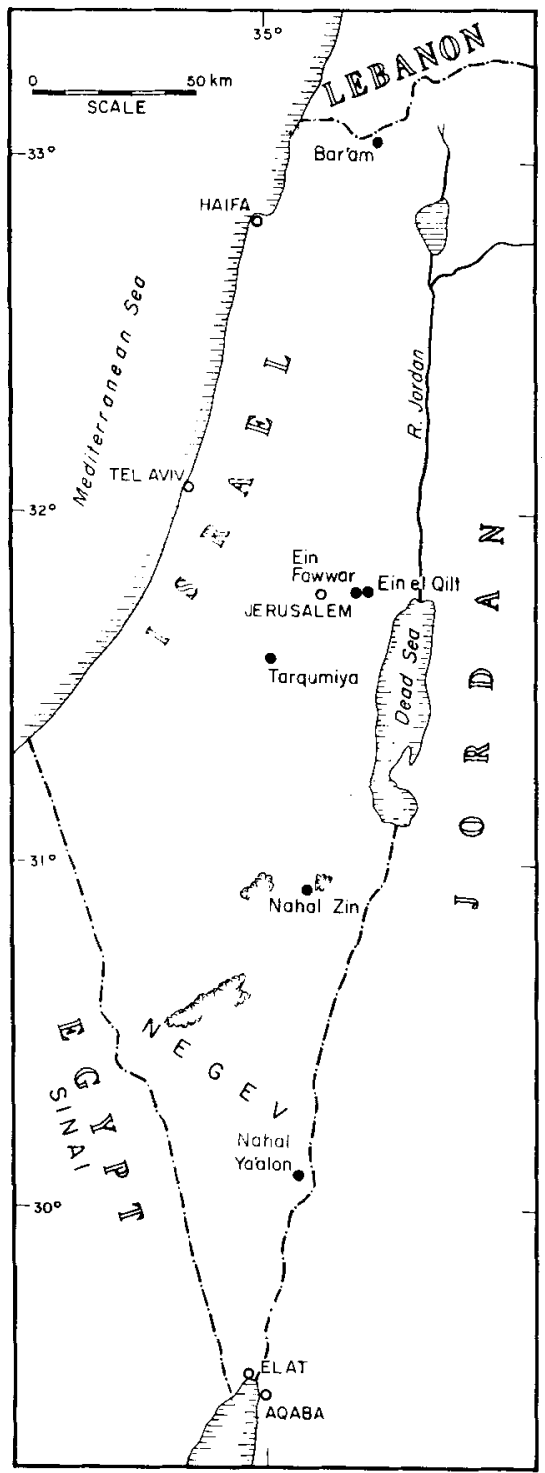

Fig. 1. Location map.
Measurements (mm).

Length Height Width

$\begin{array}{lllll}0.87 & 0.41 & 0.31 & \text { Male } & \text { Holotype } \\ 0.79 & 0.43 & 0.29 & \text { Male } & \text { Paratype } \\ 0.81 & 0.45 & 0.28 & \text { Male } & \text { Paratype } \\ 0.82 & 0.46 & 0.34 & \text { Female Paratype }\end{array}$

Description. Medium sized carapace subovate. Anterior and posterior ends broadly rounded. Dorsal margin slightly concave with faint mid-dorsal sulcus; ventral margin nearly straight. Surface entirely covered with small, round pits in the central part and subrectangular pits in the peripheral areas. Females more tumid than males.

Remarks. Cytherelloidea zinensis sp. nov. is similar to C. besrineensis Bischoff, 1964 (p. 15, pl. 3, figs. 21-22; Rosenfeld \& Rabb, 1984, p. 92, pl. 1, figs. 11-12; Aptian - Albian of Lebanon and Israel), but differs from the latter by its larger size and the finer type of reticulation. Cytherella cf. C. araucana Bertels, 1974 (Honigstein, 1984, p. 7, pl. 1, figs. 7-10; Campanian Maastrichtian of Israel) possesses lower pits and lacks reticulation in the central area.

Material and distribution. About thirty carapaces from Nahal Zin.

Stratigraphic range. Late Campanian. Zone $S-5^{*}$.

Genus Krithe Brady, Crosskey \& Robertson, 1844 Krithe echolsae Esker, 1968

(Pl. 1, figs. 5-6)

(Type No. 316)

1968 Krithe echolsae Esker; 330, PI. 3, figs. 1-4.

1982 Krithe echolsae Esker; Boukhary et al.: Pl. 2, figs. 8-9.

1982 Krithe echolsae Esker; Donze et al.: 283.

Measurements (mm)

Length Height Width

$\begin{array}{lll}0.80 & 0.39 & 0.34\end{array}$

$\begin{array}{lll}0.85 & 0.38 & 0.37\end{array}$

Remarks. Krithe echolsae Esker, 1968 was formerly recorded from the Danian of Tunisia (Esker, 1968) and the Paleocene of Egypt (Boukhary et al., 1982). It differs from K. solomoni Honigstein, 1984 (p. 11, pl. 3, figs. 9-12; Campanian of Israel) by its larger and angular posterior end.

Material and distribution. Four carapaces from Bar'am Stratigraphic range. (Early) Maastrichtian. Zone $M$.

Genus Cythereis Jones, 1849

Cythereis ornatissima (Reuss), 1846

(PI. 2, figs. 5-10)

(Type No. 319)

1846 Cytherina ornatissima Reuss: 104, Pl. 24, figs. $12-18$.

1966 Cythereis ornatissima (Reuss); Herrig: 806, Pl. 24 , figs. 3-4. 


\begin{tabular}{|c|c|c|c|c|c|}
\hline Location & Coordinates & $\begin{array}{l}\text { Thickness } \\
{[\mathrm{m}]}\end{array}$ & $\begin{array}{l}\text { No. of } \\
\text { samples }\end{array}$ & $\begin{array}{l}\text { Field } \\
\text { Mark }\end{array}$ & Lithology by \\
\hline Bar'am & $\begin{array}{l}1902 / 2723 \\
1908 / 2726\end{array}$ & 105 & 107 & $\mathrm{BR}$ & Reiss (in prep.) \\
\hline Tarqumiya & $1508 / 1974$ & 53 & 72 & PP1 & Reiss (in prep). \\
\hline Ein el Qilt & $1850 / 1381$ & 55 & 42 & $B L$ & Luz (1970) \\
\hline Ein Fawwar & $1831 / 1386$ & $\begin{array}{l}105 \\
55\end{array}$ & $\begin{array}{c}36 \\
\text { (foram.) } \\
24 \\
\text { (ostr.) }\end{array}$ & $\begin{array}{l}\mathrm{BL} \\
\mathrm{AF}\end{array}$ & $\begin{array}{l}\text { Luz (1970) } \\
\text { Flexer (unpubl.) }\end{array}$ \\
\hline Nahal Zin & $1538 / 0303$ & 93 & 136 & SMA & Reiss (in prep.) \\
\hline Nahal Ya'alon & $1602 / 9450$ & 167 & 38 & $\overline{A V I}$ & $\begin{array}{l}\text { Lifshitz et al. } \\
\text { (1985) }\end{array}$ \\
\hline
\end{tabular}

Table 1. Details of studied sections

1978 Cythereis ornatissima (Reuss); Neale (in Bate \& Robinson): 366, pl. 17, figs. 10-12.

Measurements $(\mathrm{mm})$

Length Height Width

$\begin{array}{llll}0.93 & 0.52 & 0.50 & \text { Female "spinous form" }\end{array}$

$\begin{array}{llll}0.93 & 0.53 & 0.52 & \text { Female "spinous form" }\end{array}$

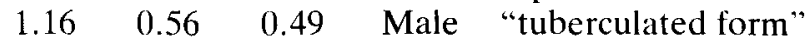

1.040 .550 .53 ?Male "tuberculated form"

Remarks. A complete synonomy for this species (up to 1966) is found in Herrig, 1966 (p. 806). Cythereis ornatissima (Reuss), 1846 occurs in Israel in two forms at different stratigraphic levels: The "spinous form" (Pl. 2, figs. 5-8) in the latest Campanian and the "tuberculated form (Pl. 2, figs. 9-10) in the Early Maastrichtian. Typical for the species are the subcentral tubercle with five distinct spines (Pl. 2, fig. 6) and the trifurcate spines at the peripheral zones (PI. 2, fig. 7). Pokorny (1963) divided C. ornatissima into several subspecies, but Herrig (1966, p. 807) explained fine differences in ornamentation within the same species resulting from paleoecological changes. This species was recorded from different stratigraphic levels of several locations around the Tethys. Minor differences occur in shape and ornamentation, in our specimens the more convex ventral margin in females and the less strongly developed median rib (see also Neale, in Bate \& Robinson, 1978, p. 367, pl. 17, fig. 11), and may be due to intraspecific variations in different palaeogeographic provinces. Our "spinous forms" are close to the subspecies ornatissima of Pokorny (1963, p. 8, pl. 1, fig. 1. pl. 3, fig. 3, pl. 4, figs. 1-7, pl. 6, figs. 1, 2, 5; Coniacian of Czechoslovakia) and the specimen figured by Herrig (1966, pl. 24, fig. 3; Maastrichtian of East Germany). The "tuberculated forms" resemble the subspecies adictyota of Pokorny (1963, p. 20, pl. 1, fig. 2, pl. 4, fig 8; Turonian of Czechoslovakia) and the specimens illustrated by Neale (in Bate \& Robinson, 1978, p. 366, pl. 17, figs 10-12; Campanian - Early Maastrichtian of England).

Material and distribution. Twelve carapaces from Bar'am, Nahal Zin and Tarqumiya.

Stratigraphic range. Latest Campanian - Early Maastrichtian. Zones S-5b, M (base).

Genus Cristaeleberis Bassiouni, 1971

Cristaeleberis ordinata Honigstein \& Rosenfeld sp. nov. (Pl. 1, figs. 7-10)

(Type No. 317)

Derivation of name. Latin, ordinatus, meaning arranged, in order, from the relatively even reticulation of the carapace.

Holotype. Male carapace, HU-6172 (Pl. 1, fig. 9). Paratypes. One male and two female carapaces (Pl. 1, figs $7,8,10$ ).

Type locality and horizon. Tarqumiya, PP1-13, coord. 1508/1074. Menuha Formation.

Diagnosis. Cristueleberis with relatively even, net-like reticulation.

Measurements $(\mathrm{mm})$.

Length Height Width

$\begin{array}{lllll}0.65 & 0.34 & 0.26 & \text { Male } & \text { Holotype } \\ 0.65 & 0.31 & 0.25 & \text { Male } & \text { Paratype } \\ 0.58 & 0.32 & 0.26 & \text { Female Paratype } \\ 0.63 & 0.31 & 0.28 & \text { Female Paratype }\end{array}$

Description. Medium sized carapace, subrectangular. Anterior end broadly rounded, posterior end bluntly pointed subcentrally, with few denticules ventrally. Both ends compressed. Dorsal and ventral margins 
straight, rather parallel in males and slightly tapering posteriorly in females. Eye-spot relatively low. Subocular rib very faint, intersepted by the coarse reticulation meshes. Weak posterodorsal rib ends centrally. Surface covered by regularly arranged, round to polygonal reticulation meshes without nodes. Dorsal view subrectangular. Internal features as for the genus (Bassiouni, 1971, p. 24). Sexual dimorphism: males longer and less tumid than females.

Remarks. The subocular rib, one of the characteristic features of the mainly Paleocene species of the genus Cristaeleberis from Jordan (Bassiouni, 1971), is generally less developed in the Late Coniacian - Maastrichtian specimens from Israel (see also Honigstein, 1984). Cristaeleberis ordinata sp. nov. differs from C. reticulata Bassiouni, 1971 (p. 26, pl. 3, figs. 5-6; Paleocene of Jordan; Honigstein, 1984, p. 34, pl. 10, figs 1-4; Late Coniacian - Maastrichtian of Israel) and from $C$. fornicata Bassiouni, 1971 (p. 29, pl. 3, figs 9-10; Maastrichtian of Jordan; Honigstein, 1984, p. 35, pl. 10, figs. 5-8; Santonian - Maastrichtian of Israel) by its weaker eye-spot, the lack of nodes and the reticulation pattern.

Material and distribution. Fifteen carapaces and valves from Nahal Zin and Tarqumiya.

Stratigraphic range. Early - Late Campanian. Zones S-4, S-5a (base).

Genus Loxoconcha Sars, 1866

Loxoconcha hebraica Honigstein \& Rosenfeld sp. nov.

(Pl. 2, figs. 1-4)

(Type No. 318)

Derivation of name. Latin, hebraicus, meaning Heb- rew, from its occurrence in Israel.

Holotype. Carapace, HU-6825 (PI. 2, fig. 3).

Paratypes. Two carapaces (P1. 2, figs. 1-2, 4).

Type locality and horizon. Nahal Zin, SMA 22, coord. 1538/0303. Mishash Formation.

Diagnosis. Loxoconcha with fine, subconcentric reticulation pattern.

Measurements ( $\mathrm{mm}$ ).

Length Height Width

$\begin{array}{llll}0.69 & 0.37 & 0.27 & \text { Holotype } \\ 0.59 & 0.31 & 0.26 & \text { Paratype } \\ 0.65 & 0.34 & 0.27 & \text { Paratype }\end{array}$

Description. Medium sized carapace, subrhomboidal. Anterior end broadly rounded, posterior end slightly pointed subcentrally. Both extremities sharply compressed. Dorsal margin straight; ventral margin sinusoidal, venter compressed, keel-like. Oval and low eye-spot. Polygonal, fine reticulation meshes arranged in more or less concentric rows; peripheral parts smooth. Dorsal view subovate. Valves nearly equal in size. Internal features not observed.

Remarks. Crane (1965, p. 229-232, pl. 8, figs. 8-20) described several species of Loxoconcha from the Senonian of the Gulf Coast, southern USA. They differ from $L$. hebraica sp. nov. mainly by their smaller size and the possession of longitudinal ridges. L. striatopunctata Veen, 1936 (see Herrig, 1966, p. 890, pl. 30, figs. 11-13; Maastrichtian of Netherlands and East Germany) is also smaller than our species and shows pronounced reticulation walls, parallel to the periphery.

Material and distribution. Eight carapaces from Nahal Zin.

Stratigraphic range. Late Campanian. Zone $S-5^{*}$.

\section{Explanation of Plate 1}

Figs. 1-4. Cytherelloidea zinensis Honigstein \& Rosenfeld sp. nov. (Late Campanian).

Fig. 1. Left valve, male carapace, paratype, Nahal Zin. SMA 22 (HU-6825), Zone S-5* (× 104).

Fig. 2. Right valve, female carapace, paratype, Nahal Zin, SMA 22 (HU-6825), Zone S-5* $(\times 96)$.

Fig. 3. Right valve, male carapace, holotype, Nahal Zin, SMA 34 (HU-6837), Zone S-5* (× 104).

Fig. 4. Dorsal view male carapace, paratype, Nahal Zin, SMA 21 (HU-6824), Zone S-5* (× 114).

Figs. 5-6. Krithe echolsae Esker (Early Maastrichtian).

Fig. 5. Left valve, carapace, Bar'am, BR 75 (HU-6735), Zone M (× 109).

Fig. 6. Dorsal view, carapace, Bar'am, BR 75 (HU-6735), Zone M (× 109).

Figs. 7-10. Cristaeleberis ordinata Honigstein \& Rosenfeld sp. nov. (Late Campanian).

Fig. 7. Dorsal view, female carapace, paratype, Tarqumiya, PP1-17 (HU-6188), Zone S-5a ( $\times 131$ ).

Fig. 8. Dorsal view, male carapace, paratype, Tarqumiya, PP1-17 (HU-6188), Zone S-5a (× 147).

Fig. 9. Left valve, male carapace, holotype, Tarqumiya, PP1-13 (HU-6172), Zone S-5a ( $\times 131)$.

Fig. 10. Right valve, female carapace, paratype, Tarqumiya, PP1-13 (HU-6172), Zone S-5a ( $\times 136)$. 


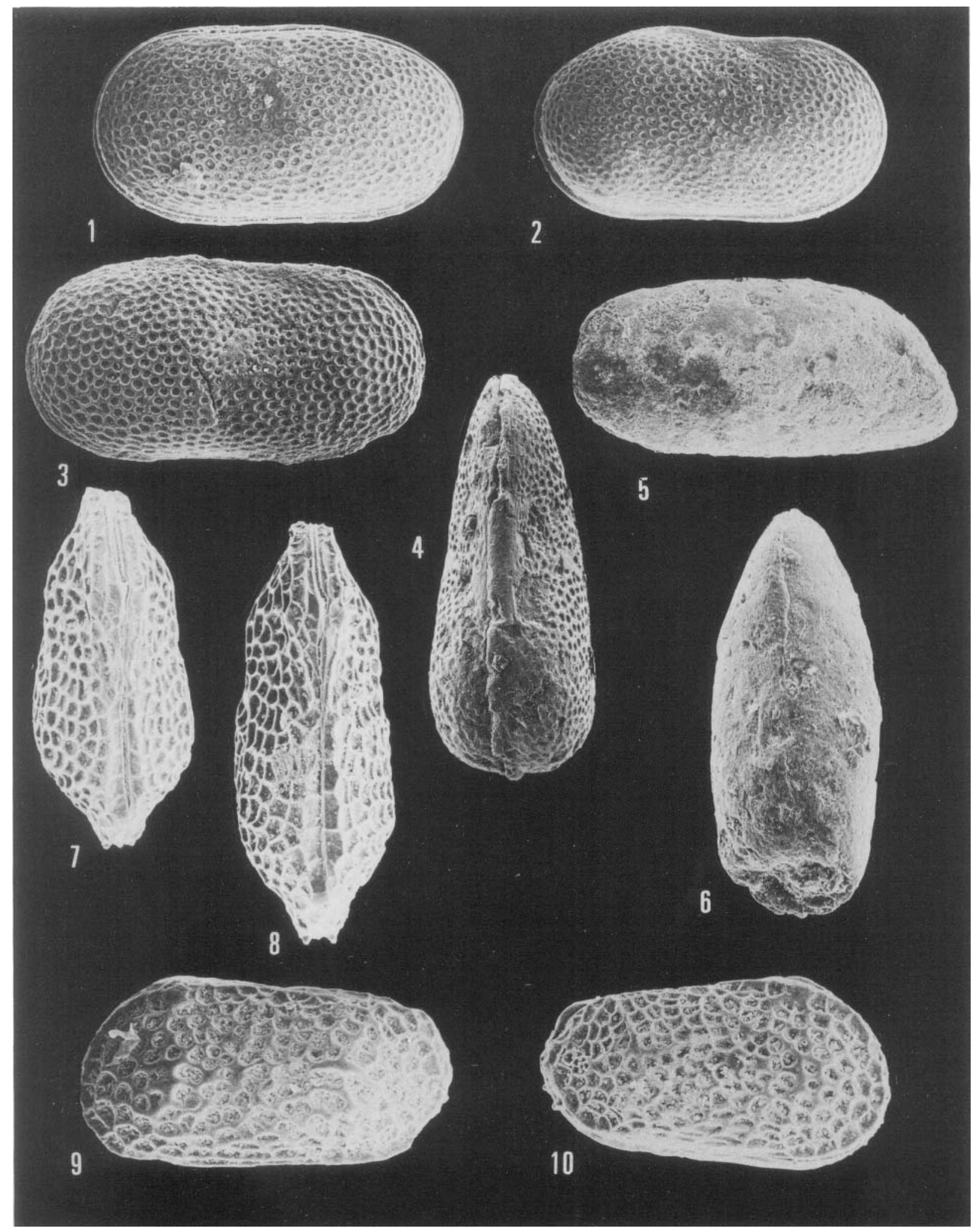




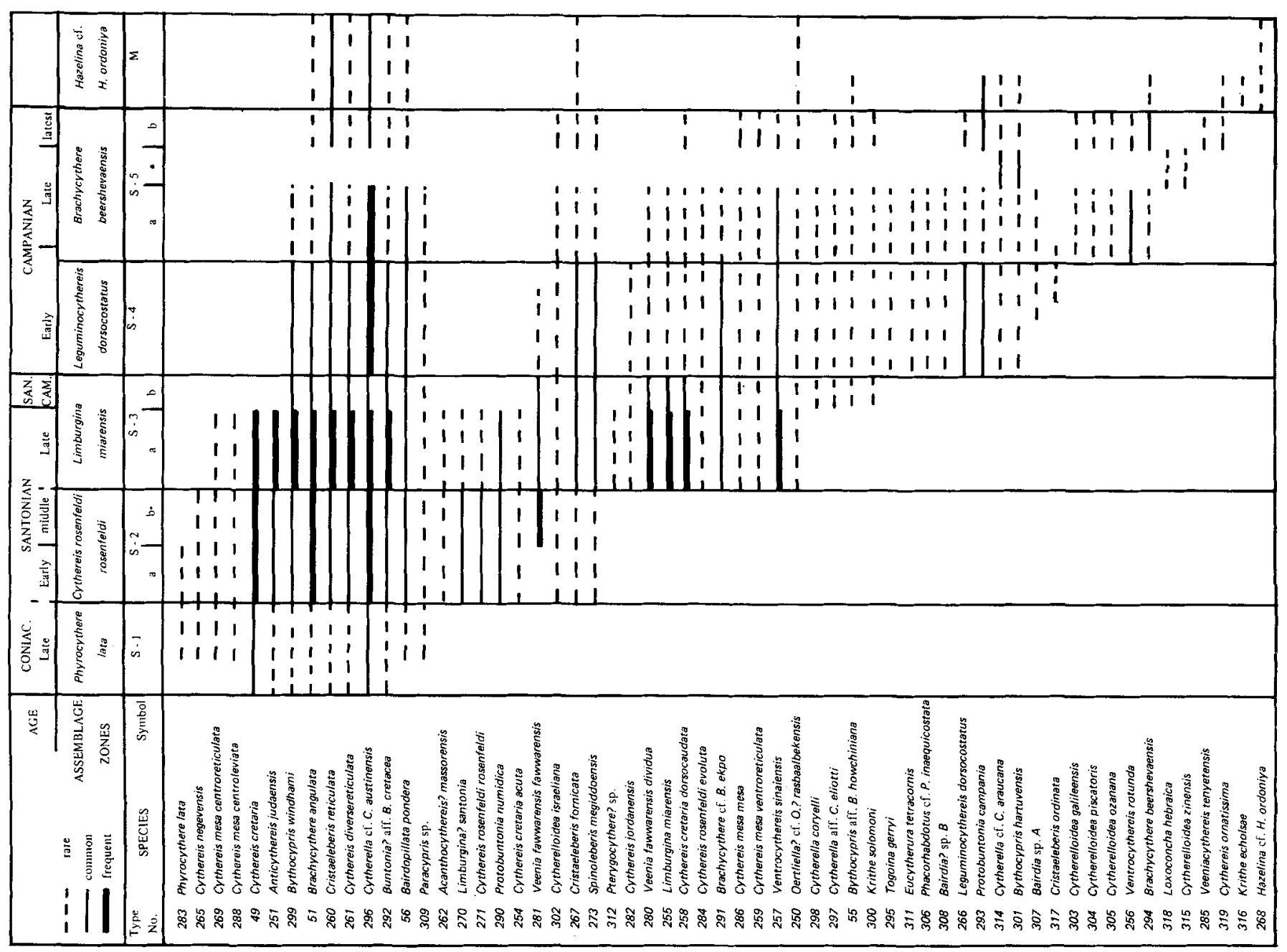

Fig. 2. General distribution chart of Senonian ostracods from Israel (modified after Honigstein, 1984).

\section{Planktonic foraminifera}

The planktonic foraminiferal fauna which occurs in our material was discussed in detail in Reiss et al. (1985, 1986) and Almogi-Labin et al. (1986), where also Globotruncanidae species were figured. In the present study, species of Heterohelicidae of stratigraphical importance in the Santonian - Campanian were recorded in the distribution charts (Figs. 3, 5, 7, 11). These species are illustrated here for the first time from the Middle East, on PI. 3: Sigalia deflaensis (Early Middle Santonian, figs. 1-3); Sigalia carpatica (Middle Santonian, fig. 4-6; compare Lipson-Benitah et al., 1985, fig. 6d); Sigalia decoratissima (Middle Santonian, Fig. 7); Ventilabrella glabrata (Late Santonian - Early Campanian, figs. 8-9) and Ventilabrella eggeri (Late Santonian - Early Campanian, figs. 10-12).

\section{CORRELATION USING PLANKTONIC FORAMINIFERAL AND OSTRACOD BIOZONATION}

The distribution of the ostracods and planktonic foraminiferal assemblages within the six studied sections (Figs. 3-12), as well as from previous works (Honigstein, 1983; Reiss et al., 1985), led to the following correlations of biozones, as presented in Fig. 13.

The Phyrocythere lata $(\mathrm{S}-1)$ assemblage zone of Late Coniacian age (Honigstein, 1984) was correlated in a northern Israel borehole section (Lipson-Benitah et al., 1985) with the Marginotruncana angusticarenata zone (Lipson-Benitah, 1980). According to Lipson -Benitah (in press), at least the upper part of the S-1 zone, which was observed in Bar'am (Fig. 6), Nahal Ya'alon (Fig. 8) and Nahal Zin (Fig. 10), belong to the lower part of the Dicarinella concavata zone (Robaszynski et al., 1984). The planktonic foraminifera of this 


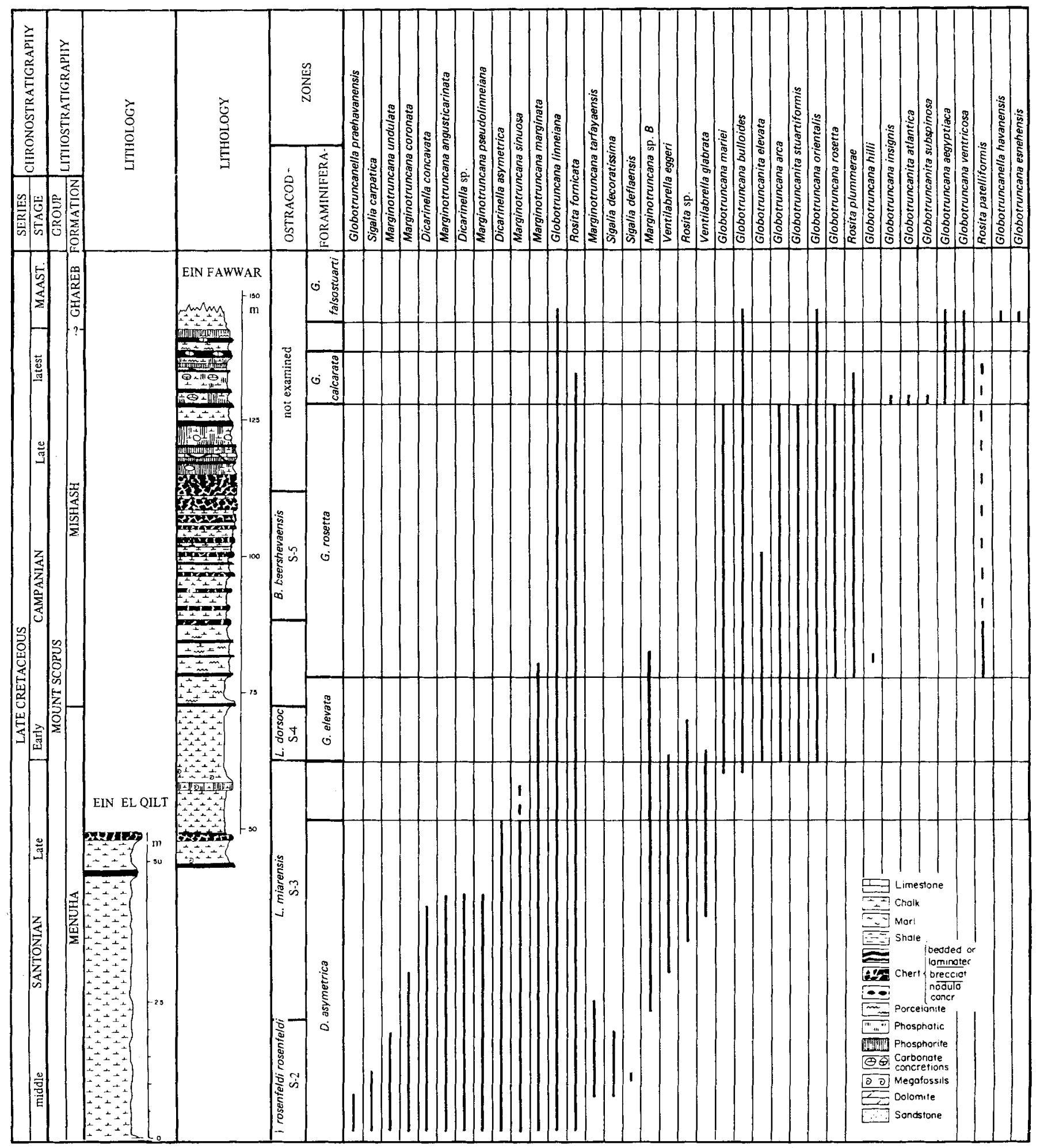

Fig. 3. Distribution chart of planktonic foraminifera from Ein el Qilt and Ein Fawwar sections. 


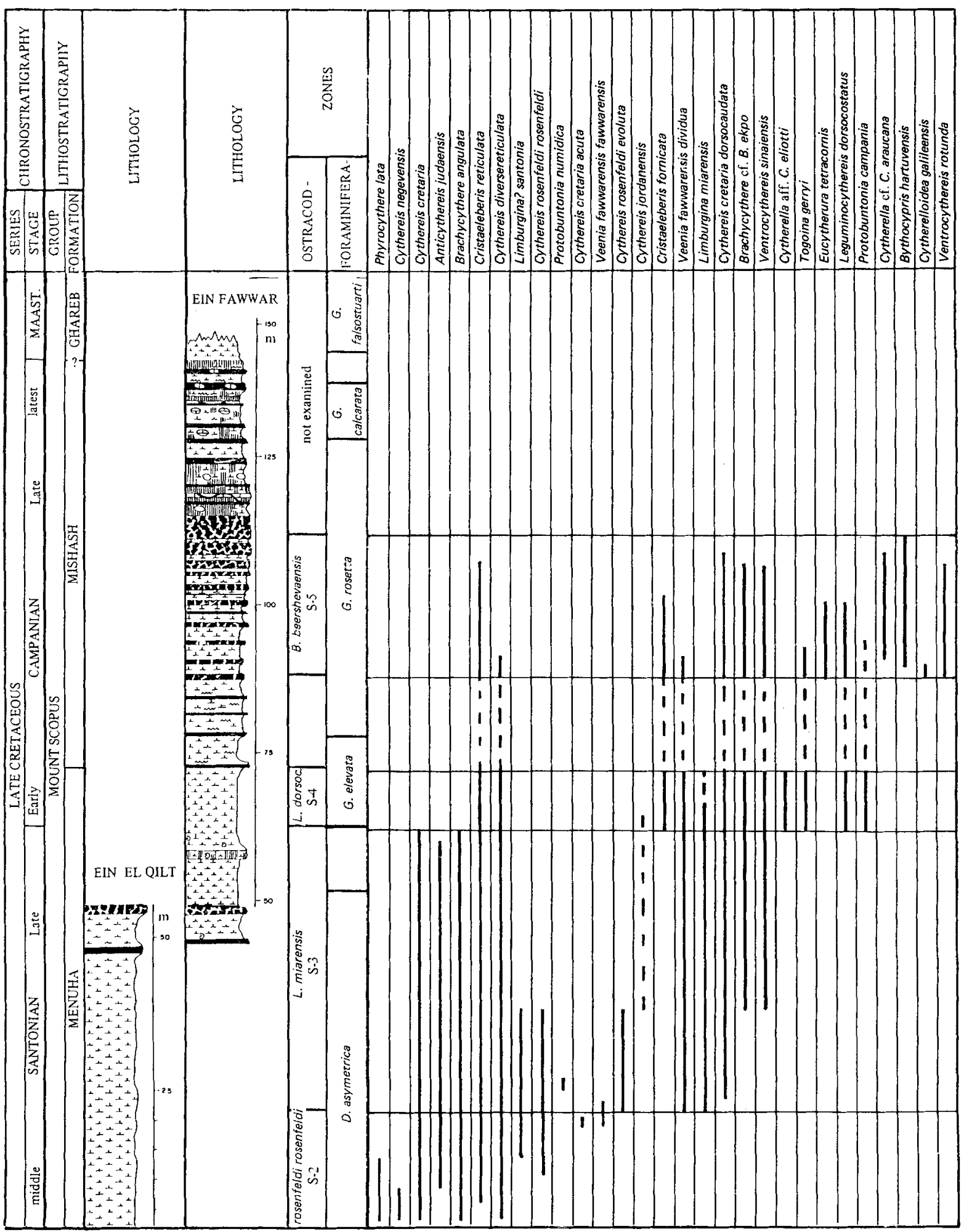

Fig. 4. Distribution chart of ostracods from Ein el Quilt and Ein Fawwar sections. 


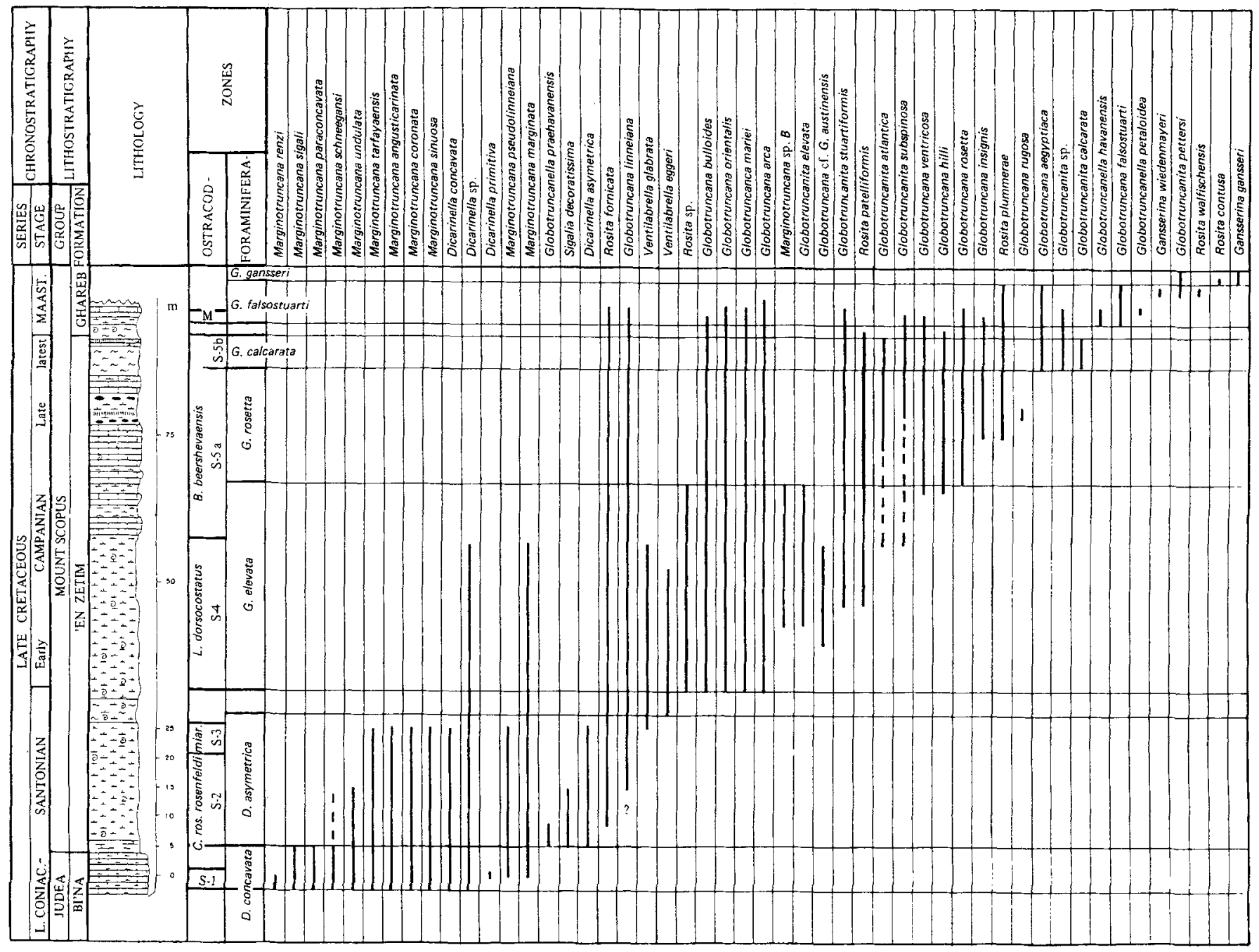

Fig. 5. Distribution chart of planktonic foraminifera from Bar'am section. Distance to samples of the Gansserina gansseri zone not to scale.

time interval are rather well developed in size and relatively abundant, whereas ostracods are minute and scarce.

The Coniacian/Santonian boundary is problematic, but may be tentatively placed at the top of the $\mathrm{S}-1$ zone. The Santonian succession is represented by high populations of ostracods and foraminifera. The Dicarinella concavata and Dicarinella asymetrica zones can be correlated with the Cythereis rosenfeldi rosenfeldi (S-2) and Limburgina miarensis (S-3) assemblage zones. Their biozone boundaries alternate (Ein el Qilt, Figs. 3-4; Bar'am, Fig. 5-6; Nahal Ya'alon, Figs. 7-8). The Santonian in the Nahal Zin section (Figs. 9-10) is reduced to about $5 \mathrm{~m}$; the Dicarinella asymetrica zone was probably therefore not observed because of the poor preservation of the foraminifera however, all ostracod zones were found.
The Santonian/Campanian boundary is defined by the common base of the Leguminocythereis dorsocostatus (S-4) and Globotruncanita elevata zones (Figs. 3-10). The Globotrunicanita elevata zone, indicative for the Early Campanian period, correlates to the $\mathrm{S}-4$ zone and it its top, to the base of the Brachycythere beershevaensis ( $\mathrm{S}-5)$ assemblage zone (Nahal Ya'alon, Fig. 8; Tarqumiya, Fig. 12). The diversity of planktonic foraminifera in the Tarqumiya section (Fig. 11) within the Early Campanian is much higher, the specimens are larger and contain a higher percentage of adults than in the Ein Fawwar exposure (Fig. 3). The ostracod diversity in these sections remains more or less constant, but the total ostracod content in the samples from Ein Fawwar is higher. These observations enhance the general W-E trend of planktonic foraminifera decrease and ostracod increase (Flexer \& Honig- 
stein, 1984).

The S-5 zone can be compared with the Late Campanian Globotruncana rosetta and the latest Campanian Globotruncanita calcarata zones (Figs. 3-12). Therefore, the former range of this ostracod zone, which can sometimes be subdivided into the subzones 5a and 5b (Honigstein, 1984: upper part of Early Campanian) must be extended into the Late and latest Campanian. The Late Campanian $\mathrm{S}-5^{*}$ subzone was recognised only from southern Israel (Honigstein, 1984; present paper: Nahal Ya'alon, Fig. 8; Nahal Zin,
Fig. 10). Two new ostracod species were found in the Nahal Zin section within this subzone, accompanying the usually rare and low diversity fauna. The $S-5 b$ subzone, contemporaneous with the Globotruncanita calcarata zone (Bar'am; Figs. 5-6; Tarqumiya, Figs. 11-12), can be differentiated from the $\mathrm{S}-5$ a subzone by the first occurrence of Veeniacythereis tenyetensis and Cythereis ornatissima (Fig. 2). Moreover, a higher ratio of pitted forms of Brachycythere and Protobuntonia versus the reticulated specimens of Ventrocythereis is found in the $\mathrm{S}-5 \mathrm{~b}$ subzone.

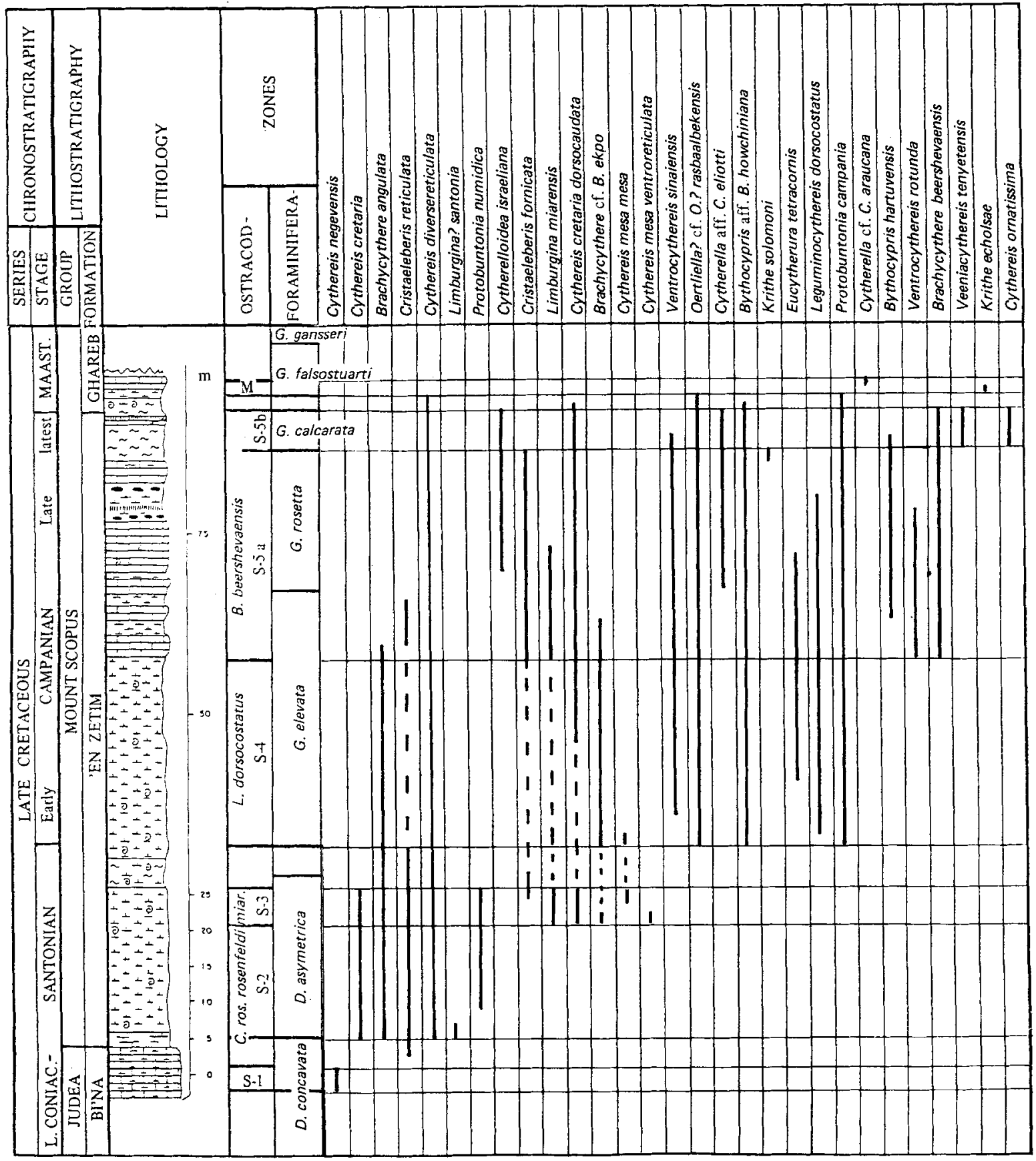

Fig. 6. Distribution chart of ostracods from Bar'am section. 


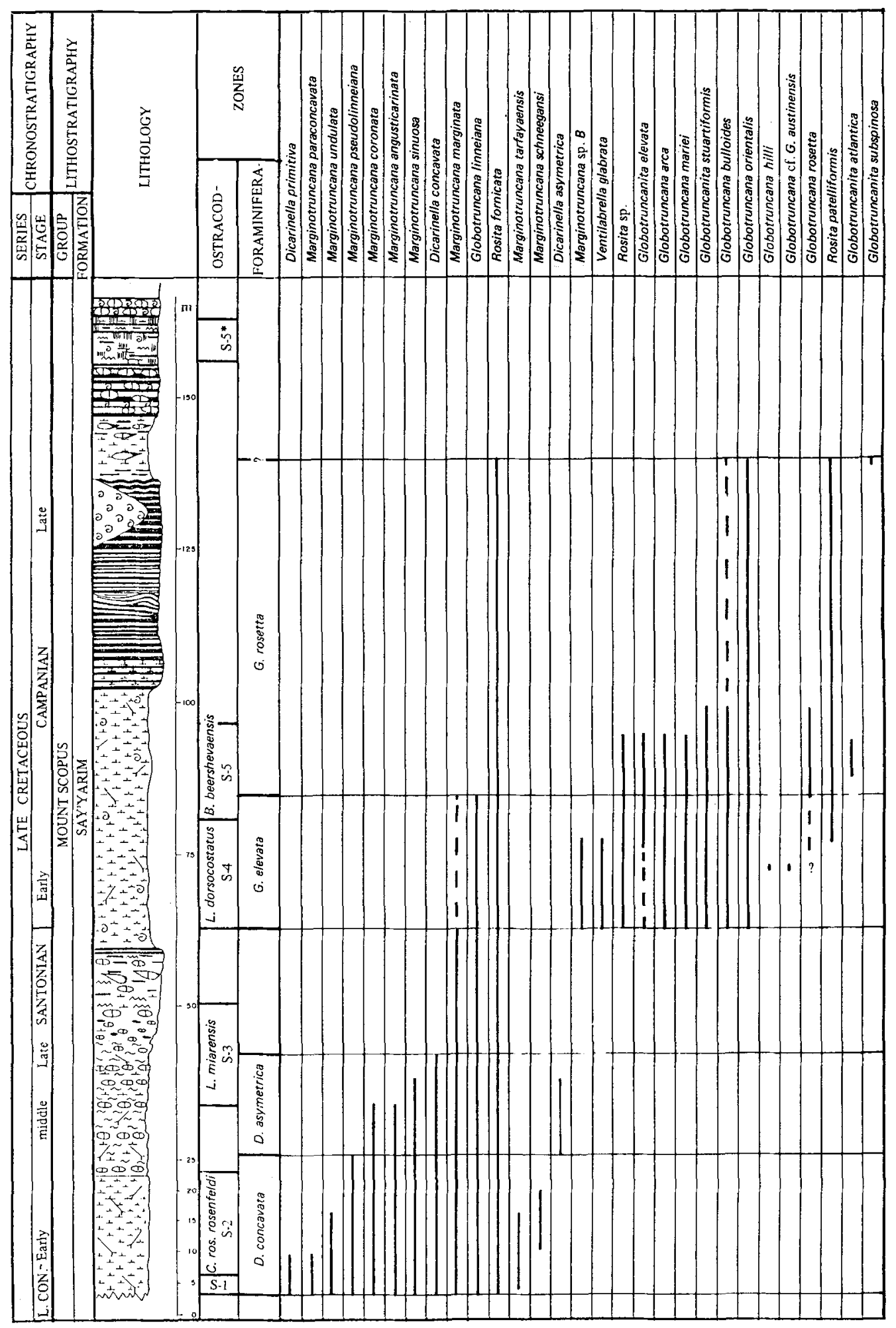

Fig. 7. Distribution chart of planktonic foraminifera from Nahal Ya'alon section. 


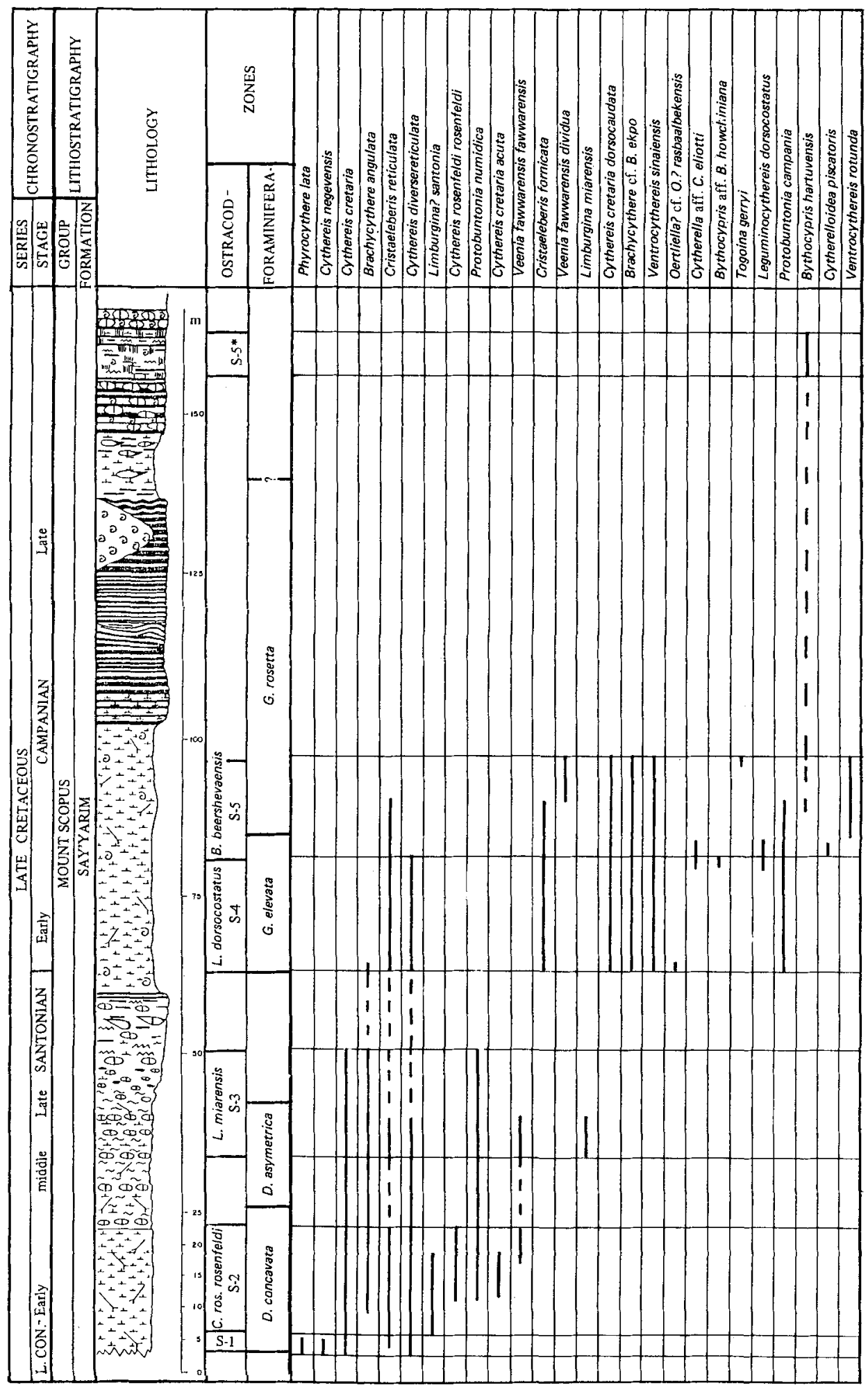

Fig. 8. Distribution chart of ostracods from Nahal Ya'alon section (modified after Lifshitz et al., 1985). 


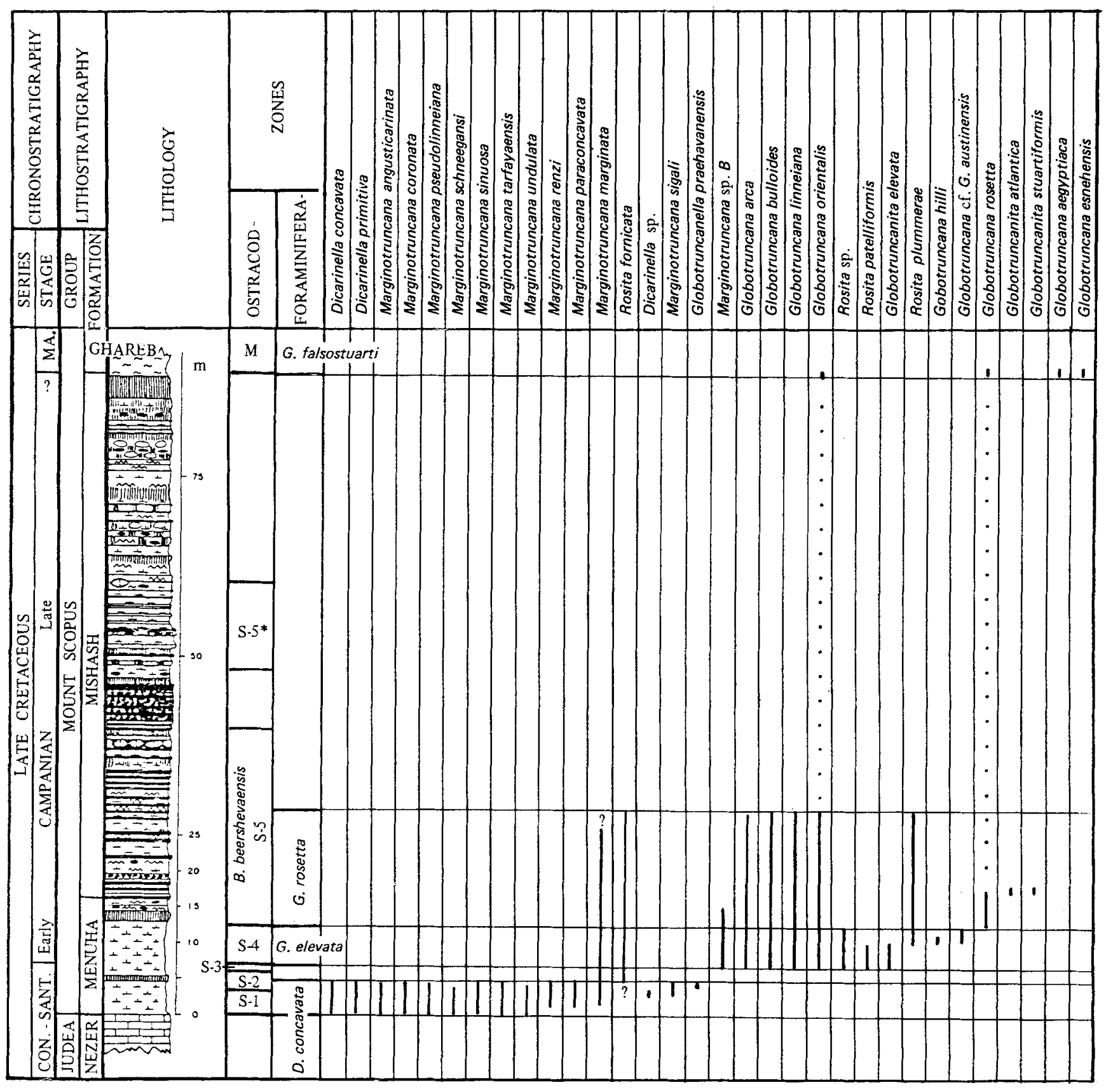

Fig. 9. Distribution chart of planktonic foraminifera from Nahal Zin section.

The Campanian/Maastrichtian boundary is not clearly defined in the Israeli succession (Reiss et al., 1985, 1986) and cannot precisely be dated by planktonic foraminifera (disappearance of Globotruncanita calcarata) and the rare ostracod fauna. The Early Maastrichtian is determined in the present study with the common range of the Giobotruncana falsostuarti and Hazelina cf. H. ordoniya (M) zones (Bar'am, Figs. 5-6; Nahal Zin, Figs. 9-10).
The combination of contemporaneous occurrences of ostracod and planktonic foraminiferal biozones enables us to date the local ostracod biostratigraphy according to the regional Tethyan planktonic foraminiferal zonation. The use of both taxa, ostracods and planktonic foraminifera, provides more datum lines and allows a finer resolution of the Senonian stratigraphy. 


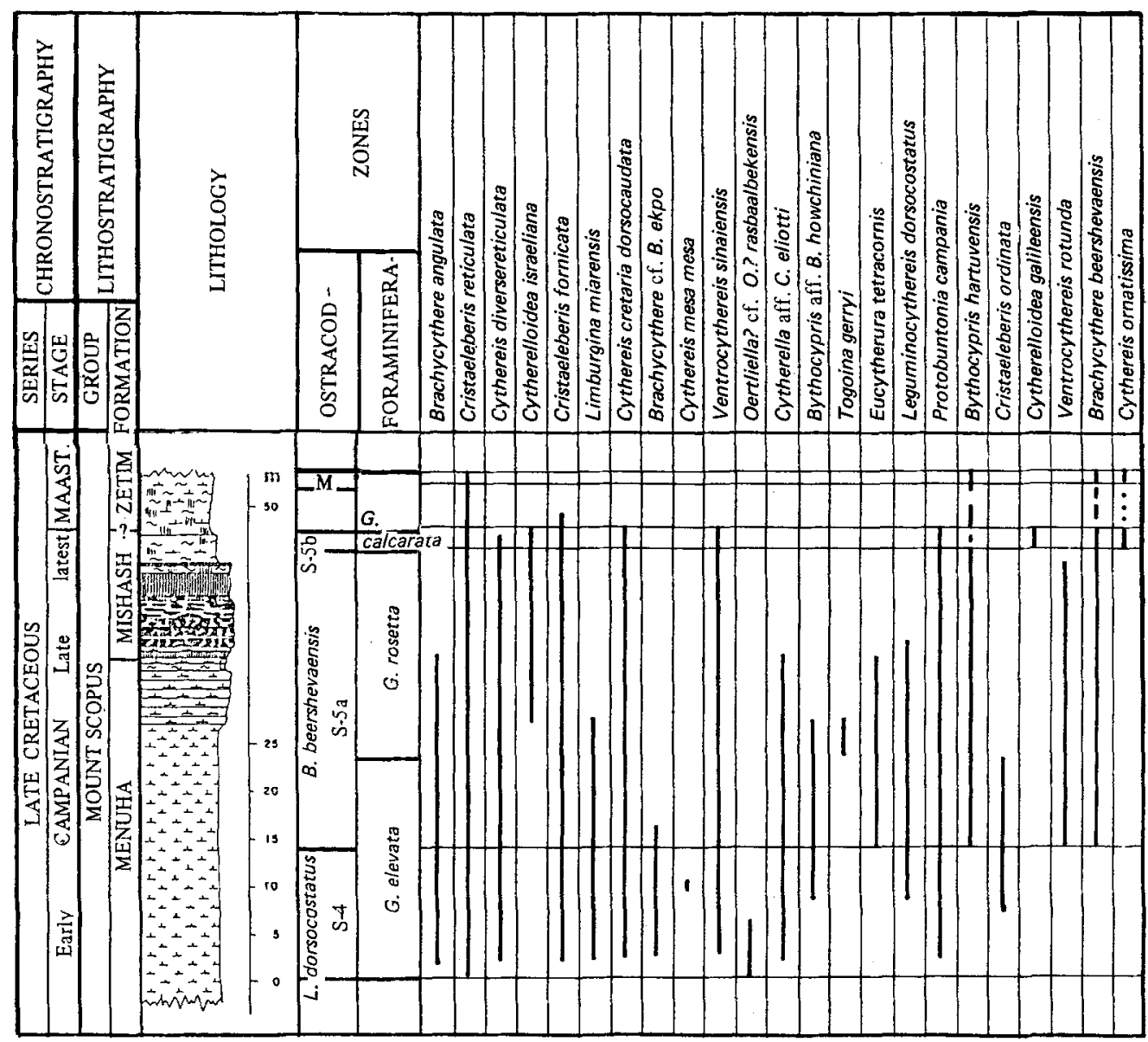

Fig. 10. Distribution chart of ostracods from Nahal Zin section.

\section{Explanation of Plate 2}

Figs. 1-4. Loxoconcha hebraica Honigstein \& Rosenfeld sp. nov.

Fig. 1. Left valve, carapace, paratype, Nahal Zin, SMA 22 (HU-6825), Zone S-5* (× 160).

Fig. 2. Right valve, same carapace $(\times 137)$.

Fig. 3. Left valve, carapace, holotype, Nahal Zin, SMA 22 (HU-6825), Zone S-5* (× 127).

Fig. 4. Dorsal view, carapace, paratype, Nahal Zin, SMA 33 (HU-6844), Zone S-5* (× 137).

Figs. 5-10. Cythereis ornatissima (Reuss) (latest Campanian - Early Maastrichtian).

Fig. 5. Left valve, female carapace, "spinous form", Bar'am, BR 71 (HU-6731), Zone S-5b ( $\times 100)$.

Fig. 6. Subcentral node of the same carapace with five distinctive, subdivided spines (scale bar $=100 \mu \mathrm{m}$ ).

Fig. 7. Trifurcated spines in the posteroventral area of the same carapace (scale bar $=10 \mu \mathrm{m}$ ).

Fig. 8. Right valve, female carapace, "spinous form", Bar'am, BR 71 (HU-6731), Zone S-5b (× 91).

Fig. 9. Left valve, male carapace, "tuberculated form", Nahal Zin, SMA 111 (HU-6896), Zone M (base) ( $\times 75)$.

Fig. 10. Right valve, ?male carapace, "tuberculated form", Nahal Zin, SMA 111 (HU-6896), Zone M (base) (× 85). 


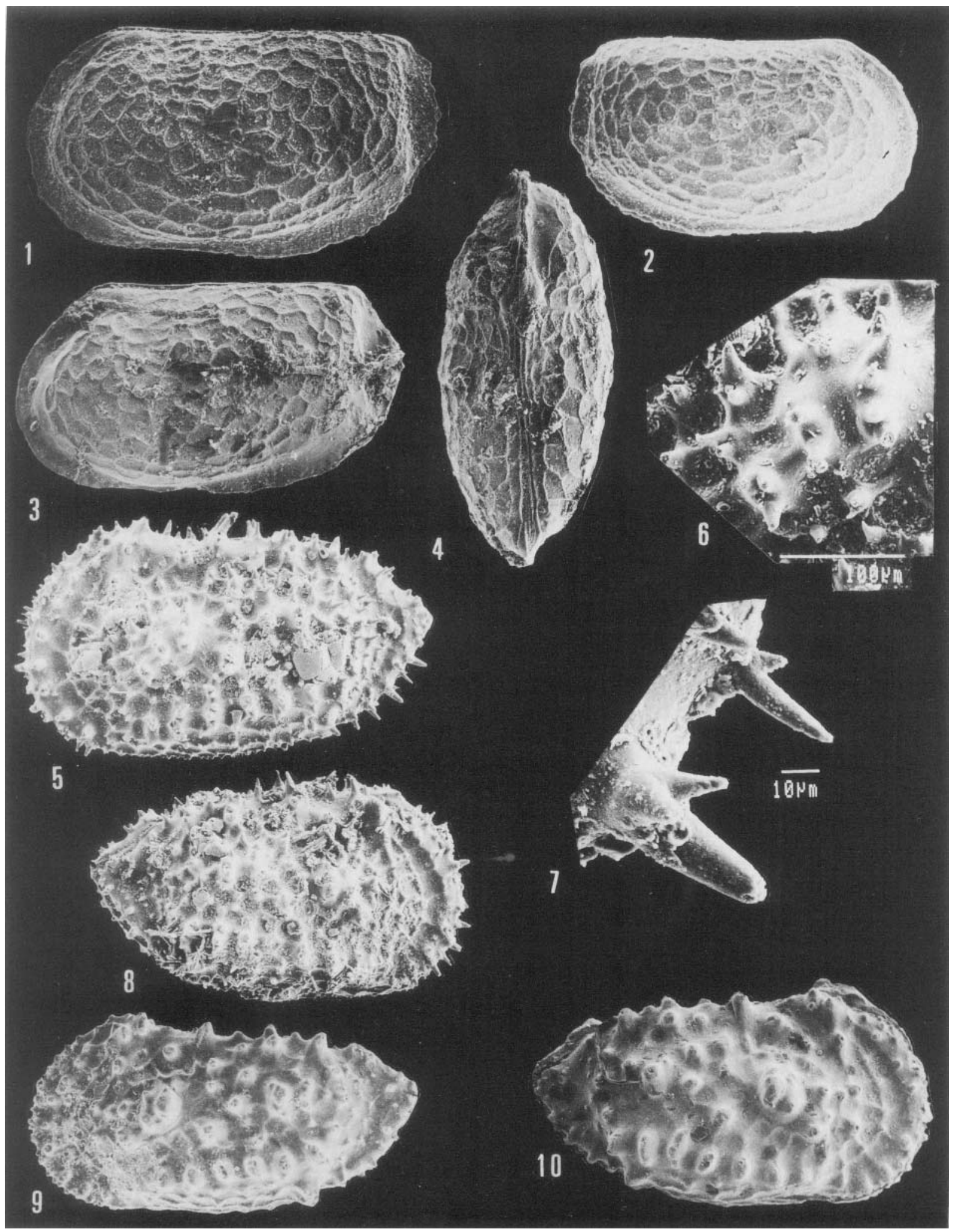




\section{ACKNOWLEDGEMENTS}

The authors wish to thank Prof. Z. Reiss, Hebrew University, Jerusalem, for helpful comments and discussions. Thanks are due to Y. Haas and Y. Ginot, Hebrew University, Jerusalem, as well as to $M$. Dvorachek and Y. Levy, Geological Survey of Israel, Jerusalem, for the SEM photographs.

This study is part of the project: Senonian biostratigraphy in Israel and was supported by grant No. 032.7032 of the Israel Ministry for Energy and Infrastructure and grant No. 032.7100 of the Belfer Center for Energy Research.

Manuscript received December 1986 Revised manuscript accepted April 1987

\section{REFERENCES}

Almogi-Labin, A., Reiss, Z. \& Caron, M. 1986. Senonian Globotruncanidae from Israel. Eclog. geol. Helv., Lausanne, 79 (3), 849-895, pls. 1-11.

Bassiouni, M. A. 1971. Ostracoda (Mauritsininae und Trachyleberindinae) und ihre Bedeutung fuer die Biostratigraphie des Maastricht und des Alttertiaer von Jordanien. Geol. Jb., Berlin, 106, 5-51, pls. 1-5.

Bischoff, G. 1964. Ostracoden-Studien im Libanon: Die Gattung Cytherelloidea im Oberen Jura und in der Unterkreide. Senckenberg. leth., Frankfurt, 45 (1-4), 1-27, pls. $1-3$.

Boukhary, M. A., Guernet, C. \& Mansour, H. 1982. Ostracodes du Tertiaire inferieur de l'Egypte. Cahiers de Micropaleonotologie, 1982 (1), 13-20, pls. 1-2.

Crane, M. J. 1965. Upper Cretaceous ostracoda of the Gulf Coast area. Micropaleonotology, New York, 11 (2), 191 -254 , pls. $1-9$.

Donze, P., Colin, J.-P., Damotte, R., Oertli, H. J., Peypouquet, J. P. \& Said, R. 1982. Les ostracodes du Campanien terminal à L'Eocene terminal de la coupe d' Kef, Tunisie Nord occidentale. Bull. Cent. Rech. Pau, 6 (2), 272-335, pls. 1-13.

Esker, G. C. 1968. Danian ostracodes from Tunisia. Micropaleontology, New York, 14 (3), 319-333, pls. 1-4.

Flexer, A. \& Honigstein, A. 1984. The Senonian section in Israel - Lithostratigraphy, biostratigraphy and sea level changes. Cretaceous Research, 5, 303-312.

\section{Explanation of Plate 3}

Figs. 1-3. Sigalia deflaensis (Sigal) (Early - Middle Santonian).

Fig. 1. Ein el Qilt, BL 100) (HU-3376), D. asymetrica Zone $(\times 105)$.

Fig. 2. Ein el Qilt, BL 100) (HU-3376), D. asymetrica Zone $(\times 110)$.

Fig. 3. Ein el Qilt, BL $100(\mathrm{HU}-3376)$, D. asymetrica Zone $(\times 135)$.

Figs. 4-6. Sigalia carpatica Salaj \& Samuel (Middle Santonian).

Fig. 4. Ein el Qilt, BL 100 (HU-3376), D. asymetrica Zone (× 125).

Fig. 5. Ein el Qilt, BL 87 (HU-3363), D. asymetrica Zone $(\times 100)$.

Fig. 6. Ein el Qilt, BL 87 (HU-3363), D. asymetrica Zone ( $\times 180)$.

Fig. 7. Sigalia decoratissima (de Klasz) (Middle Santonian).

Ein el Qilt, BL 100) $(\mathrm{HU}-3376)$, D. asymetrica Zone $(\times 100)$.

Figs. 8-9. Ventilabrella glabrata Cushman (Late Santonian - Early Campanian).

Fig. 8. Ein el Qilt, BL 156 (HU-3624), D. asymetrica Zone (× 110).

Fig. 9. Ein el Qilt, BL 156 (HU-3624), D. asymetrica Zone ( $\times 185)$.

Figs. 10-12. Ventilabrella eggeri Cushman (Late Santonian - Early Campanian).

Fig. 10. Ein el Qilt, BL 144 (HU-3618), D. asymetrica Zone $(\times 100)$.

Fig. 11. Ein el Qilt, BL 156 (HU-3624), D. asymetrica Zone $(\times 110)$.

Fig. 12. Ein el Qilt, BL 156 (HU-3624), D. asymetrica Zone $(\times 155)$. 


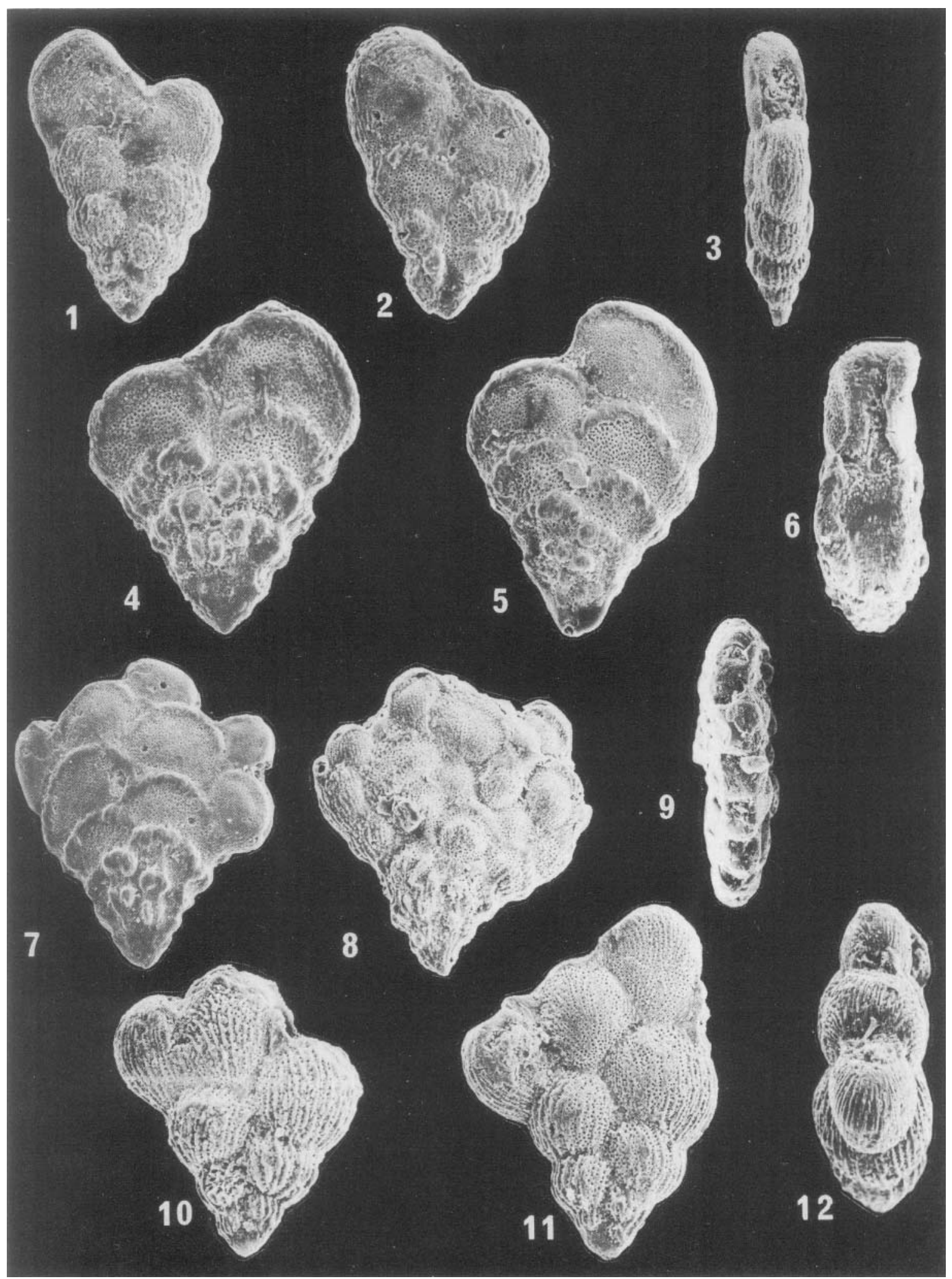




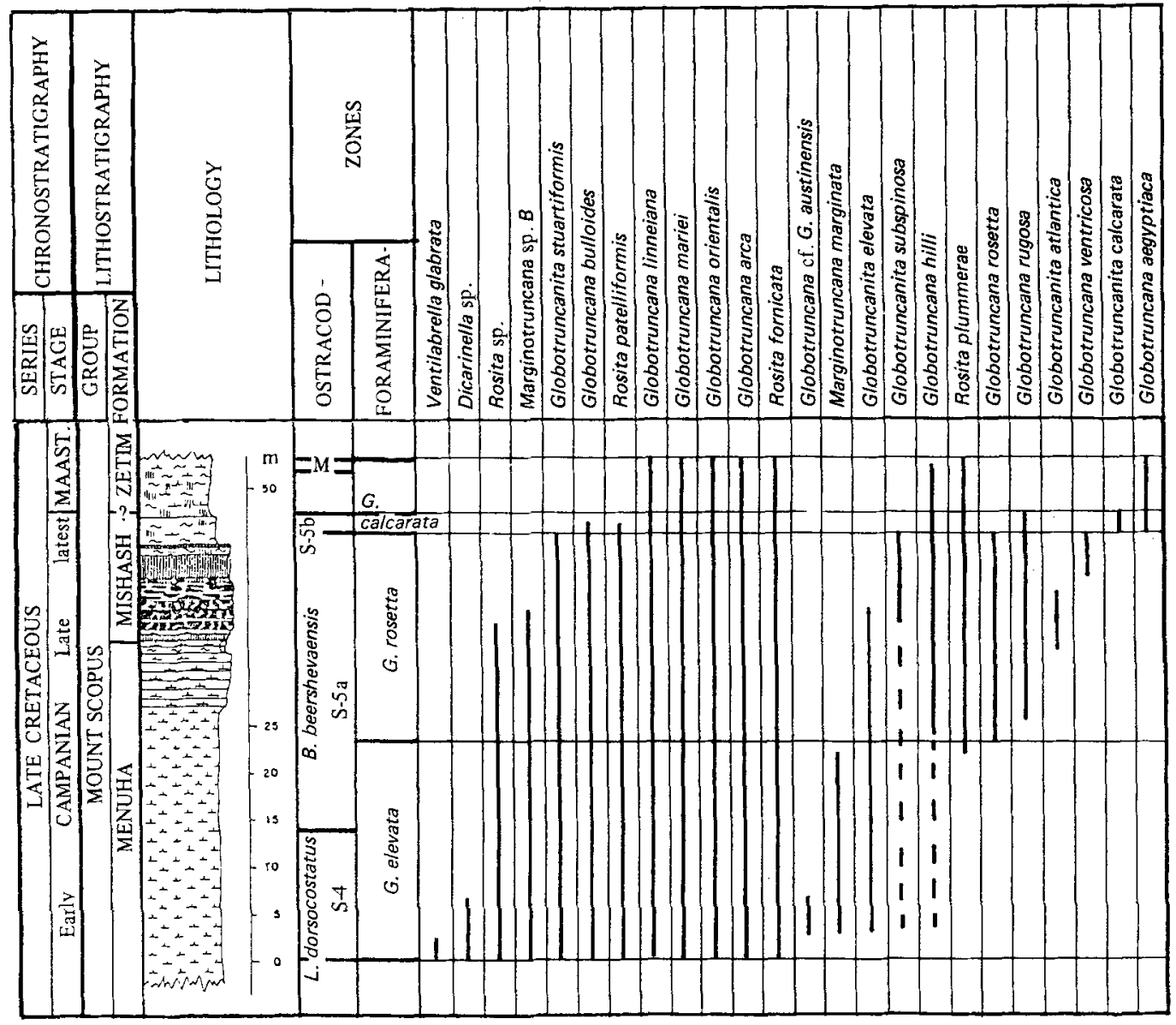

Fig. 11. Distribution chart of planktonic foraminifera from Tarqumiya section.

Herrig, E. 1966. Ostracoden aus der Weissen Schreibkreide (Unter-Maastricht) der Insel Ruegen. Palaeont. Abh., Berlin, Abt. A, 2 (4), 693-1024, pls. 1-45.

Honigstein, A. 1983. Senonian ostracodes from Israel (Taxonomy, Biostratigraphy). Geol. Surv. Isr., Rep. S/14/83, 1-326, pls. $1-16$.

Honigstein, A. 1984. Senonian ostracodes from Israel. Bull. Geol. Surv. Israel, 78, 1-48, pls. 1-15.

Lifshitz, A., Honigstein, A., Livnat, A., Roded, R. \& Flexer, A. 1985. The Say'yarim Formation, Nahal Ya'alon area, southern Arava Valley: Lithostratigraphy, ostracode biostratigraphy and paleoenvironmental implications. Israel J. Earth Sci., Jerusalem, 34 (4), 193-204.

Lipson-Benitah, S. 1980. Albian to Coniacian zonation of the western Coastal Plain of Israel. Cretaceous Research, 3 , $3-12$.

Lipson-Benitah, S. (in press). The planktic foraminiferal biostratigraphy of the Coniacian in Israel - A correction. Cretaceous Research.

Lipson-Benitah, S., Honigstein, A. \& Rosenfeld, A. 1985. Early Turonian to Early Senonian biostratigraphy (foraminifera and ostracodes) of Damun-7 borehole, Galilee, northwestern Israel. Neues Jb. Geol. Palüont. Mh., Stuttgart, 1985 (2), 100-114.
Luz, B. 1970. Biostratigraphy and numerical significance of faunal assemblages in the Upper Cretaceous strata of Judean Desert. Unpub. M. Sc. thesis, Hebrew University, Jerusalem, 1-52, pls. 1-7 [in Hebrew].

Neale, J. W. 1978. The Cretaceous. In Bate, R. \& Robinson, E. (Eds), A stratigraphical index of British ostracoda. Geol. J., Spec. Issue no. 8, 325-384, pls. 1-17, Seel House Press, Liverpool.

Moshkovitz, S. 1984. Late Cretaceous calcareous nannofossil biostratigraphy of the Mount Scopus Group, Israel. Geol. Surv. Isr., Current Research, 4 (1983/1984), 46-55.

Pokorny, V. 1963. The revision of Cyunereis ornatissima (Reuss, 1846) (Ostracoda, Crustacea). Rozp. Ceskos. Akad. Ved., Rada matem., 73 (6), 3-59, pls. I-7.

Reiss, Z., Almogi-Labin, A., Honigstein, A., Lewy, Z., Lipson-Benitah, S., Moshkovitz, S. \& Zaks, Y. 1985. Late Cretaceous multiple stratigraphic framework of Israel. Israel J. Earth Sci., Jerusalem, 34 (4), 147-160.

Reiss, Z., Almogi-Labin, A.. Lewy, Z. and Moshkovitz, S. 1986. Biostratigraphic datums in the Senonian of Israel. Proc. Konink Nederl. Akad. Wu'fnschuppen, Ser. B, 89 (1), 95-104.

Reuss, A. E. 1846. Die Versteinerunge'n der Boehmischen Kreideformation. 2. Abth., 1-48, pls 14-51, Schweizbart, Stuttgart. 


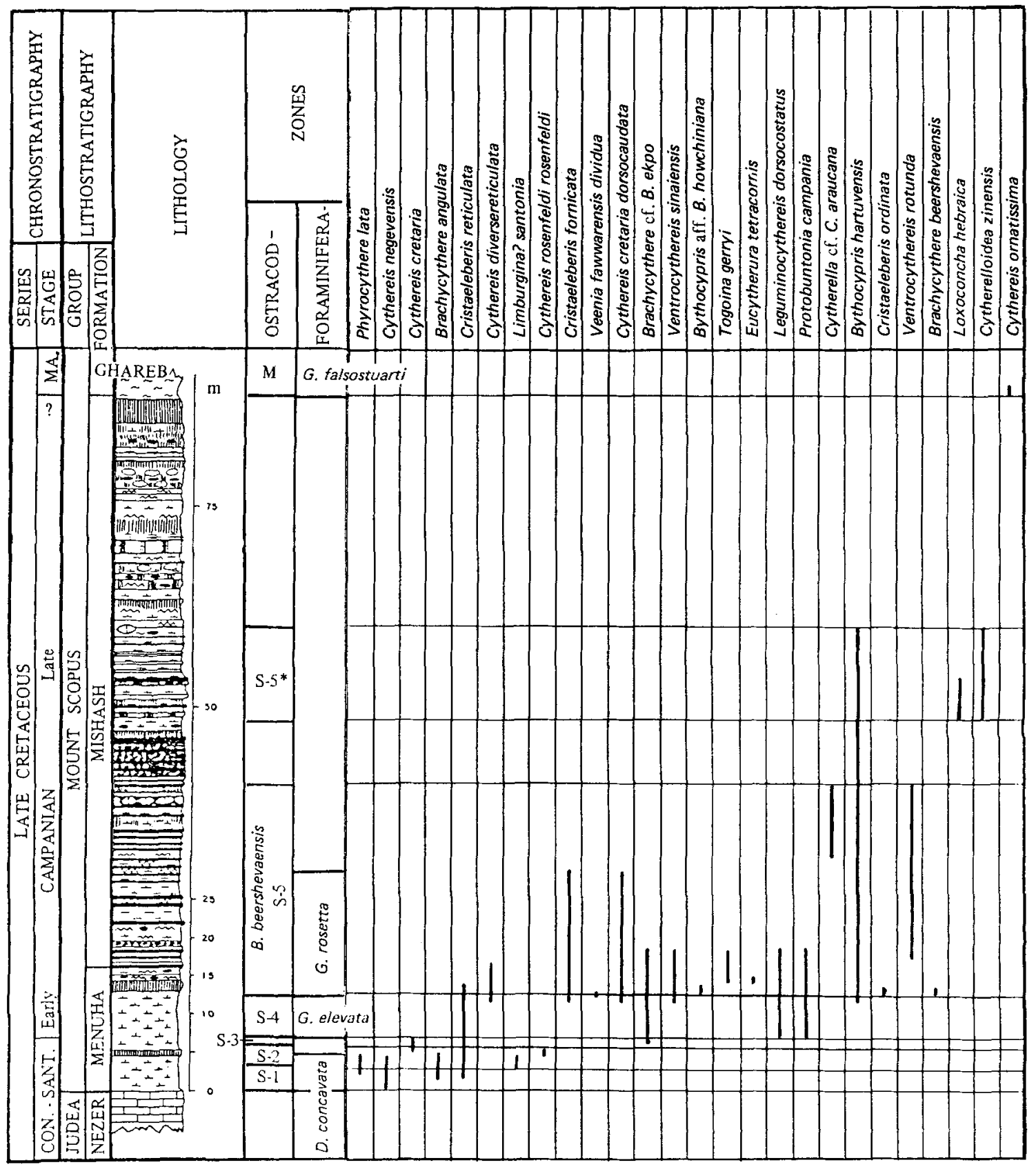

Fig. 12. Distribution chart of ostracods from Tarqumiya section. 


\begin{tabular}{|c|c|c|}
\hline $\mathrm{AGE}$ & $\begin{array}{l}\text { FORAMINIFERA- } \\
\text { ZONE }\end{array}$ & $\begin{array}{l}\text { OSTRACOD- } \\
\text { ZONE }\end{array}$ \\
\hline $\begin{array}{l}\text { MAASTRICHT. } \\
\text { (Early) }\end{array}$ & $\begin{array}{c}\text { Globotruncana } \\
\text { fa/sostuarti }\end{array}$ & $\begin{array}{l}\text { Hazelina cf. } \\
\text { H. ordoniya } \\
\text { M }\end{array}$ \\
\hline $\begin{array}{l}\text { CAMPANIAN } \\
\text { latest }\end{array}$ & $\begin{array}{c}\text { Globotruncanita } \\
\text { calcarata }\end{array}$ & \multirow{3}{*}{ 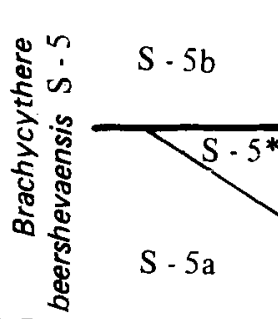 } \\
\hline $\begin{array}{l}\text { CAMPANIAN } \\
\text { Late }\end{array}$ & $\begin{array}{l}\text { Globotruncana } \\
\text { rosetta }\end{array}$ & \\
\hline \multirow[b]{2}{*}{$\begin{array}{l}\text { CAMPANIAN } \\
\text { Early }\end{array}$} & \multirow[b]{2}{*}{$\begin{array}{l}\text { Globotruncanita } \\
\text { elevata }\end{array}$} & \\
\hline & & $\begin{array}{l}\text { Leguminocythereis } \\
\text { dorsocostatus } \\
\text { S - } 4\end{array}$ \\
\hline \multirow{2}{*}{$\begin{array}{l}\text { SANTONIAN } \\
\text { middle }\end{array}$} & \multirow[t]{2}{*}{$\begin{array}{l}\text { Dicarinella } \\
\text { asymetrica }\end{array}$} & $\begin{array}{l}\text { Limburgina } \\
\text { miarensis } \\
\mathrm{S} \cdot 3\end{array}$ \\
\hline & & \multirow{2}{*}{$\begin{array}{l}\text { Cythereis rosenfeldi } \\
\text { rosenfeldi } \\
\mathrm{S}-2 \\
\begin{array}{c}\text { Phyrocythere } \\
\text { lata } \\
\mathrm{S}-1\end{array} \\
\end{array}$} \\
\hline $\begin{array}{l}\text { SANTONIAN } \\
\text { Early } \\
\text { - } \\
\text { CONIACIAN } \\
\text { Late }\end{array}$ & Dicarinella & \\
\hline
\end{tabular}

Fig. 13. Correlation of planktonic foraminifera and ostracod biozonation during the Senonian of Israel.
Robaszynski, F., Caron, M., Gonzales Donoso, J. M., Wonders, A. A. H. (Eds.) 1984. Atlas of Late Cretaceous Globotruncanids. Revue. Micropaléont, Paris, 26 (3-4), 145-305, pls. 1-54.

Rosenfeld, A. \& Raab, M. 1984. Lower Cretaceous ostracodes from Israel and Sinai. Israel J. Earth Sci., Jerusalem, 33 (3), 85-134, pls. 1-11. 